\title{
PENGEMBANGAN MULTIMEDIA INTERAKTIF PADA PEMBELAJARAN KOSAKATA BAHASA INGGRIS DI SEKOLAH DASAR
}

\author{
Hevy Anna Lubis ${ }^{1}$ dan Harun Sitompul ${ }^{2}$ \\ Guru SD IT Al Iklas Medan ${ }^{1}$ dan Universitas Negeri Medan ${ }^{2}$ \\ hevyannalubis@yahoo.co.id dan prof_runsit@yahoo.co.id ${ }^{2}$
}

\begin{abstract}
Abstrak: Penelitian ini bertujuan untuk: (1) menghasilkan media pembelajaran interaktif yang layak digunakan, mudah dipelajari dan dapat dipakai untuk pembelajaran individual, (2) untuk mengetahui keefektifan media pembelajaran interaktif yang dikembangkan untuk pembelajaran kosaka Bahasa Inggris pada siswa sekolah dasar. Jenis penelitian ini adalah penelitian pengembangan yang menggunakan model pengembangan produk Borg dan Gall yang dipadu dengan model pengembangan pembelajaran Dick dan Carey. Hasil penelitian menunjukkan: (1) uji ahli materi Bahasa Inggris berada pada kualifikasi sangat sesuai (95,08 \%), (2) uji ahli desain pembelajaran berada pada kualifikasi sangat sesuai (93,96 \%), (3) uji ahli rekayasa perangkat lunak dan desain grafis berada pada kualifikasi sangat sesuai (86,70\%), uji coba perorangan berada pada kualifikasi sangat sesuai (91,43\%), uji coba kelompok kecil berada pada kualifikasi sangat sesuai (93,63\%), uji coba lapangan berada pada kualifikasi sangat sesuai (97.96\%). Dengan demikian, pengujian hipotesis membuktikan bahwa terdapat perbedaan yang signifikan antara hasil belajar siswa yang dibelajarkan dengan menggunakan media pembelajaran interaktif dan hasil belajar siswa yang dibelajarkan dengan menggunakan media pembelajaran buku teks.
\end{abstract}

Kata Kunci: Pengembangan media pembelajaran, hasil belajar Bahasa Inggris

Abstract: This study aims to: (1) generate media interactive learning proper use, easy to learn and can be used for individual learning, (2) to determine the effectiveness of interactive learning media developed for Kosaka learning English in primary school students. This type of research is the development of research that uses models Borg and Gall product development combined with the learning development model Dick and Carey. The results showed: (1) The English test materials experts are at a very appropriate qualifications $(95.08 \%)$, (2) test the instructional design experts are at a very appropriate qualifications (93.96\%), (3) test software engineering expert software and graphic design are at a very appropriate qualifications $(86.70 \%)$, individual testing is at a very appropriate qualifications (91.43\%), small group trial is at a very appropriate qualifications (93.63\%), field trials are at a very appropriate qualifications (97.96\%). Thus, hypothesis testing proves that there are significant differences between student learning outcomes that learned using interactive instructional media and student learning outcomes that learned by using learning media textbook.

Keywords: development of learning media, learning outcomes english

\section{PENDAHULUAN}

Pembangunan di bidang pendidikan dewasa ini dapat dilihat dari peningkatan sistem pelaksanaan pendidikan dan pengembangan pembelajaran yang selalu diusahakan dari waktu ke waktu seperti tercantum dalam Undang-Undang Republik Indonesia Nomor 20 tahun 2003 tentang Sistem Pendidikan Nasional yang menggariskan bahwa pembangunan di bidang pendidikan adalah upaya mengembangkan kemampuan dan membentuk watak serta peradaban bangsa yang bermartabat dalam rangka mencerdaskan kehidupan bangsa, bertujuan untuk mengembangkan potensi peserta didik agar menjadi manusia yang beriman dan bertaqwa kepada Tuhan Yang Maha Esa, berakhlak mulia, sehat, berilmu, 
cakap, kreatif, mandiri dan menjadi warga negara yang demokratis serta bertanggung jawab. Pada hakikatnya tujuan pendidikan nasional adalah meningkatkan daya saing generasi muda dalam masyarakat global. Sehingga perlu adanya pertimbangan untuk meletakkan dasar yang kuat bagi peserta didik kita pada masa periode emas atau di tingkat dasar dalam rangka mencapai tujuan pendidikan nasional.

Bahasa Inggris merupakan alat untuk berkomunikasi secara lisan dan tulisan. Berkomunikasi adalah memahami dan mengungkapkan informasi, pikiran, perasaan, dan mengembangkan ilmu pengetahuan, teknologi, dan budaya. Bahasa Inggris adalah bahasa global yang sangat berperan dalam interaksi dan komunikasi (lingua franca) global seiring dengan kemajuan dan persaingan globalisasi. Bahasa Inggris digunakan sebagai bahasa resmi di lebih dari 60 negara di dunia. Ini menunjukkan bahwa Bahasa Inggris adalah alat komunikasi yang sangat penting untuk banyak orang di seluruh dunia.

Tujuan pengajaran bahasa Inggris di SD mencakup (1) Mendengarkan, yaitu memahami instruksi, informasi, dan cerita yang sangat sederhana yang disampaikan secara lisan dalam konteks kelas, sekolah, dan lingkungan sekitar. (2) Berbicara, yaitu mengungkapkan makna secara lisan dalam wacana interpersonal dan transaksional yang sangat sederhana dalam bentuk instruksi dan informasi dalam konteks kelas, sekolah, dan lingkungan sekitar. (3) Membaca, yaitu membaca nyaring dan memahami makna dalam instruksi, informasi, teks fungsional pendek, dan teks deskriptif bergambar sangat sederhana yang disampaikan secara tertulis dalam konteks kelas, sekolah, dan lingkungan sekitar. (4) Menulis, yaitu menuliskan kata, ungkapan, dan teks fungsional pendek yang sangat sederhana dengan ejaan dan tanda baca yang tepat.

Keterbatasan pemahaman kosakata bahasa Inggris mengakibatkan terhambatnya pencapaian kompetensi berbahasa. Dalam pemerolehan bahasa, baik bahasa ibu maupun bahasa asing, diperlukan proses penguasaan bahasa yang dilakukan oleh anak secara natural (alami) dan belajar di dalam kelas, yaitu siswa yang diajar oleh guru.
Dalam upaya meningkatkan pembelajaran Bahasa Inggris yang menarik dan menyenangkan bagi siswa masih diperlukan berbagai terobosan dalam mengembangkan inovasi pembelajaran dan pemenuhan sarana dan prasarana pendidikan yang memadai. Seorang guru dituntut untuk selalu berinovasi dalam mengajar, menguasai bahan yang diajarkan dan terampil untuk mengajarkannya.

Pembelajaran Bahasa Inggris di SD haruslah sederhana, mudah, dan menyenangkan. Pembelajaran tidak boleh membebani siswa karena itu akan sangat berpengaruh pada prestasi siswa.

Hendaknya pembelajaran disajikan dalam bentuk visual karena lebih mudah diserap dan diingat daripada sekedar narasi. Oleh karena itu perlu diterapkan Pembangunan di bidang pendidikan dewasa ini dapat dilihat dari peningkatan sistem pelaksanaan pendidikan dan pengembangan pembelajaran yang selalu diusahakan dari waktu ke waktu seperti tercantum dalam Undang-Undang Republik Indonesia Nomor 20 tahun 2003 tentang Sistem Pendidikan Nasional yang menggariskan bahwa pembangunan di bidang pendidikan adalah upaya mengembangkan kemampuan dan membentuk watak serta peradaban bangsa yang bermartabat dalam rangka mencerdaskan kehidupan bangsa, bertujuan untuk mengembangkan potensi peserta didik agar menjadi manusia yang beriman dan bertaqwa kepada Tuhan Yang Maha Esa, berakhlak mulia, sehat, berilmu, cakap, kreatif, mandiri dan menjadi warga negara yang demokratis serta bertanggung jawab (Depdiknas, UU No. 20 Th. 2003: Pasal 3). Pada hakikatnya tujuan pendidikan nasional adalah meningkatkan daya saing generasi muda dalam masyarakat global. Sehingga perlu adanya pertimbangan untuk meletakkan dasar yang kuat bagi peserta didik kita pada masa periode emas atau di tingkat dasar dalam rangka mencapai tujuan pendidikan nasional.

Bahasa Inggris merupakan alat untuk berkomunikasi secara lisan dan tulisan. Berkomunikasi adalah memahami dan mengungkapkan informasi, pikiran, perasaan, dan mengembangkan ilmu pengetahuan, teknologi, dan budaya. Bahasa Inggris adalah bahasa global yang sangat berperan dalam 
interaksi dan komunikasi (lingua franca) global seiring dengan kemajuan dan persaingan globalisasi. Bahasa Inggris digunakan sebagai bahasa resmi di lebih dari 60 negara di dunia. Ini menunjukkan bahwa Bahasa Inggris adalah alat komunikasi yang sangat penting untuk banyak orang di seluruh dunia.

Tujuan pengajaran bahasa Inggris di SD mencakup mendengarkan, yaitu memahami instruksi, informasi, dan cerita yang sangat sederhana yang disampaikan secara lisan dalam konteks kelas, sekolah, dan lingkungan sekitar, berbicara, yaitu mengungkapkan makna secara lisan dalam wacana interpersonal dan transaksional yang sangat sederhana dalam bentuk instruksi dan informasi dalam konteks kelas, sekolah, dan lingkungan sekitar, membaca, yaitu membaca nyaring dan memahami makna dalam instruksi, informasi, teks fungsional pendek, dan teks deskriptif bergambar sangat sederhana yang disampaikan secara tertulis dalam konteks kelas, sekolah, dan lingkungan sekitar, dan menulis, yaitu menuliskan kata, ungkapan, dan teks fungsional pendek yang sangat sederhana dengan ejaan dan tanda baca yang tepat.

Keterbatasan pemahaman kosakata bahasa Inggris mengakibatkan terhambatnya pencapaian kompetensi berbahasa. Dalam pemerolehan bahasa, baik bahasa ibu maupun bahasa asing, diperlukan proses penguasaan bahasa yang dilakukan oleh anak secara natural (alami) dan belajar di dalam kelas, yaitu siswa yang diajar oleh guru.

Dalam upaya meningkatkan pembelajaran Bahasa Inggris yang menarik dan menyenangkan bagi siswa masih diperlukan berbagai terobosan dalam mengembangkan inovasi

pembelajaran dan pemenuhan sarana dan prasarana pendidikan yang memadai. Seorang guru dituntut untuk selalu berinovasi dalam mengajar, menguasai bahan yang diajarkan dan terampil utnuk mengajarkannya.

Pembelajaran Bahasa Inggris di SD haruslah sederhana, mudah, dan menyenangkan. Pembelajaran tidak boleh membebani siswa karena itu akan sangat berpengaruh pada prestasi siswa. Hendaknya pembelajaran disajikan dalam bentuk visual karena lebih mudah diserap dan diingat daripada sekedar narasi. Oleh karena itu perlu diterapkan suatu penyampaian informasi melalui paradigma learning by seing, hearing and doing misalnya dengan memanfaatkan teknologi multimedia.

Perkembangan proses pembelajaran Bahasa Inggris yang terjadi di SD IT AlIkhlas ini, dari tahun ke tahun memang belum memiliki perkembangan yang signifikan. Hal ini dapat dilihat pada nilai rata-rata Bahasa Inggris kelas IV(empat) yang masih rendah.

Dari data yang didapat peneliti pada observasi analisis sebelumnya, nilai rata-rata Bahasa Inggris siswa Kelas IV SD IT AlIkhlas masih rendah. Faktor rendahnya pencapaian hasil belajar Bahasa Inggris siswa kelas IV disebabkan karena beberapa siswa merasa bahasa Inggris cukup sulit dan terasa asing sehingga kurang menarik minat belajar siswa, siswa hanya menggunakan buku teks tanpa ada media interaktif dan guru menyampaikan materi hanya dengan metode konvensional. Sumber belajar yang dipakai selama ini di dalam pembelajaran ternyata hanya terbatas pada buku-buku cetak saja.

Hasil observasi yang dilakukan oleh peneliti (Anna, 2013) melalui tes angket terhadap 60 orang siswa kelas IV sebagai sampel dan 15 orang guru menunjukkan bahwa $100 \%$ siswa dan $75 \%$ dari guru- guru yang mengajar membutuhkan media pembelajaran dengan multimedia interaktif yang merupakan sumber belajar alternatif sebagai upaya dalam membantu proses pembelajaran yang lebih menarik untuk meningkatkan hasil belajar siswa.

Mengingat berbagai keterbatasan yang dimiliki oleh peneliti maka pengembangan media pembelajaran interaktif dibatasi pada : 1) Media pembelajaran Bahasa Inggris yang akan dikembangkan adalah berbasis multimedia interaktif pada kelas IV SD, dan 2) Materi Bahasa Inggris yang akan dikembangkan dalam media pembelajaran ini adalah hanya meliputi salah satu bagian dari kosakata dasar (Basic Vocabulary) dalam Bahasa Inggris, yaitu kata benda (Noun) yang meliputi (1) benda-benda universal di dalam kelas dan rumah yang dapat dihitung dan bersifat nyata, dan (2) nama bagian tubuh manusia. Multimedia pembelajaran adalah multimedia yang digunakan di dalam proses pembelajaran, 
untuk menyalurkan pesan sehingga dapat digunakan untuk merangsang pikiran, perasaan, perhatian dan kemauan siswa untuk belajar sehingga secara sengaja terjadi proses belajar. Media pembelajaran dapat disebut interaktif apabila peserta didik tidak hanya melihat dan mendengar tetapi secara nyata berinteraksi dan dilibatkan langsung dengan media pembelajaran itu.

Penggunaan multimedia dalam pembelajaran dapat memberikan manfaat yang besar bagi guru dan siswa. Manfaat yang dapat diperoleh adalah proses pembelajaran lebih menarik, lebih interaktif, jumlah waktu mengajar dapat dikurangi, kualitas belajar siswa dapat ditingkatkan dan proses belajar mengajar dapat dilakukan di mana dan kapan saja, serta sikap belajar siswa dapat ditingkatkan.

Untuk mendapatkan media pembelajaran yang efektif, efisien dan berdaya tarik, peneliti menggunakan prinsipprinsip desain pembelajaran dan desain media dalam pengembangan media pembelajaran interaktif. Media yang dikembangkan berdasarkan masukan pada kegiatan analisis kebutuhan untuk memperoleh informasi bahwa media pembelajaran interaktif yang akan dikembangkan memang dibutuhkan dan dapat memberi kemudahan bagi guru sebagai fasilitator pembelajaran dan siswa sebagai konsumen belajar. Oleh karena itu diperlukan uji coba dan revisi sebagai prosedur yang harus dilakukan untuk menghasilkan media pembelajaran interaktif yang layak untuk digunakan.

Hasil yang dikembangkan berupa media pembelajaran yang berbasis multimedia tidak hanya mendengar dan melihat video dan suara, tetapi juga memberikan respon yang aktif, dan respon itu yang menentukan kecepatan dan sekuensi penyajian ( Arsyad, 2002 :36). Media ini disebut CD Multimedia Interaktif. Disebut multimedia dikarenakan bahwa media ini memiliki unsur audio-visual (termasuk animasi). Disebut interaktif karena media ini dirancang dengan melibatkan respon pemakai secara aktif. Di dalam CD ini juga akan terdapat game puzzle yang berisikan materi pembelajaran dalam bentuk game yang akan membuat siswa merasa senang, tertarik, dan tertantang untuk melakukannya. Kondisi ini disesuaikan dengan karakteristik anak pada kelas IV SD berusia kira-kira 10 tahun yaitu: (1) senang bermain; (2) ingin tahu semuanya; (3) senang dan berminat pada pelajaranpelajaran tertentu saja; (4) mengejar nilai yang tinggi saja yang dianggap bagus di sekolah; dan (5) anak-anak suka membentuk kelompok dengan teman sebayanya. Perencanaan multimedia pembelajaran interaktif ini mengacu pada model pengembangan Borg \& Gall (1983).

Perencanaan

multimedia pembelajaran interaktif ini berada dalam kawasan pengembangan. Menurut Seels \& Richey (1994: 28-37) kawasan pengembangan berakar pada produksi media. Media pengembangan pembelajaran kosakata (vocabulary) Bahasa Inggris berbasis multimedia interaktif yang dikembangkan oleh peneliti akan sangat sesuai dengan kebutuhan siswa kelas IV SD. Hal ini dikarenakan, multimedia interaktif yang akan dikembangkan oleh peneliti dan yang akan digunakan oleh pengguna (siswa) dapat ditelusuri materi ajarnya sesuai dengan kemampuan dan latar belakang pengetahuan yang dimiliki siswa, disamping itu akan membuat pengguna merasa lebih nyaman dalam mempelajari isi media secara berulangulang.

Materi yang disajikan sesuai dengan tuntutan kurikulum dan berhubungan dengan kehidupan siswa sehari-hari baik di rumah maupun di sekolah ataupun di tempat-tempat lainnya. Seluruh materi yang ditampilkan, diaplikasikan dalam bentuk audio-visual yang didukung oleh fitur-fitur gambar animasi yang menarik dan tombol eksekusi, sehingga jika siswa mengklik kata-kata yang diinginkan akan terdengar pengucapannya dan terlihat penulisan katanya. Dengan cara ini, siswa akan lebih memahami makna dan penulisan dari kata-kata yang sedang dipelajarinya. Sementara itu, animasi dapat meningkatkan pembelajaran kosakata apabila digabungkan dengan narasi yang informatif dan menarik. Media ini dikemas dalam bentuk software dan disimpan di dalam sebuah CD ( Compact Disk ), terasa ringan ketika dipegang, sehingga siswa dapat dengan mudah membawanya kemanapun dia pergi. Kondisi ini akan sangat sesuai dengan karakteristik anak usia SD, dimana keadaan tubuhnya belum kuat untuk membawa barang yang terlalu berat, selalu 
ingin tahu akan sesuatu, ingin belajar realistis, suka membentuk kelompok sebayanya, suka dengan permainan (game) dan selalu bergerak aktif. Simulasi dan visualisasi yang ditampilkan dalam multimedia interaktif kepada peserta didik akan dapat mengembangkan aspek kognitifnya, instruksi yang didengar dari media tersebut akan mempengaruhi kebiasaannya (aspek afektif) untuk selalu melakukannya berulang-ulang tanpa rasa takut salah dan malu, dan dilakukan selalu dengan menggunakan anggota tubuhnya(aspek psikomotorik).

Penggunaan multimedia interaktif dalam pembelajaran memang memiliki beberapa keuntungan seperti : (a) sistem pembelajaran lebih inovatif dan interaktif, (b) mampu menimbulkan rasa senang selama pembelajaran berlangsung sehingga akan menambah motivasi siswa, (c) mampu menggabungkan antara teks, gambar, audio, musik, animasi gambar atau video dalam satu kesatuan yang saling mendukung sehingga tercapai tujuan pembelajaran,(d) mampu menvisualisasikan materi yang abstrak, (e) media penyimpanan yang relative gampang dan fleksibel, (f) membawa obyek yang sukar didapat atau berbahaya ke dalam lingkungan belajar, (g) menampilkan obyek yang terlalu besar kedalam kelas, dan (h) menampilkan obyek yang tidak dapat dilihat dengan mata telanjang. Perencanaan multimedia pembelajaran interaktif ini mengacu pada model pengembangan Borg \& Gall (1983) dan berada dalam kawasan pengembangan.

Menurut Seels \& Richey (1994: 2837) kawasan pengembangan berakar pada produksi media. Pengembangan adalah proses penterjemahan spesifikasi desain ke dalam bentuk fisik. Kawasan pengembangan mencakup banyak variasi teknologi yang digunakan dalam pembelajaran, tidak hanya terdiri atas perangkat keras pembelajaran tapi juga perangkat lunaknya, bahan-bahan audio visual, serta program atau paket yang merupakan paduan berbagai bagian. Di dalam kawasan pengembangan terdapat keterkaitan yang komplek antara teknologi dan teori yang mendukung baik desain, pesan, maupun strategi pembelajaran.

Arsyad (2002: 15) mengatakan bahwa salah satu fungsi utama media pembelajaran adalah sebagai alat bantu mengajar yang turut mempengaruhi iklim, kondisi, dan lingkungan belajar yang ditata dan diciptakan oleh guru. Menurut Wood (2001: 15), penggunaan multimedia pembelajaran berpotensi meningkatkan pembelajaran kosakata. Dalam multimedia pembelajaran dapat disajikan bentuk permainan, hyperlink, hypertext, dan animasi.

Bentuk permainan dapat memberi stimulasi eksternal dan menampilkan berbagai bentuk grafik. Bentuk hyperlink memberi kesempatan kepada siswa untuk memperoleh kata-kata baru dalam berbagai konteks melalui akses yang cepat ke teks dan grafik yang diinginkan siswa. Bentuk hypertext memungkinkan siswa mengklik kata-kata yang diinginkan untuk mendengar pengucapannya dan meningkatkan pemahaman terhadap kata-kata baru yang dipelajari. Sementara itu, animasi dapat meningkatkan pembelajaran kosakata apabila digabungkan dengan narasi yang informatif dan menarik.

Berdasarkan pernyataan dari beberapa ahli media tersebut, maka dapat disimpulkan bahwa dengan penggunaan media dapat meningkatkan motivasi, rangsangan dan mempermudah siswa dalam memahami materi yang disampaikan dan dapat digunakan oleh guru sebagai alat bantu mengajar untuk meningkatkan kualitas siswa yang aktif dan interaktif sehingga dapat mendukung kelancaran kegiatan pembelajaran disekolah dalam mencapai tujuan pembelajaran.

\section{METODE}

Penelitian ini dilaksanakan di Sekolah Dasar IT Al-Ikhlas Jl.Jamin Ginting pasar 7 no.56 Padang Bulan Medan. Adapun langkahlangkah dalam penelitian ini menggunakan 2 tahap yakni tahap pertama adalah untuk pengembangan media dengan menghasilkan suatu produk dan tahap kedua adalah untuk mengetahui keefektifan produk.Untuk menghasilkan produk multimedia pembelajaran yang layak pakai dan sesuai dengan kebutuhan, maka perlu ditempuh suatu pendekatan penelitian. Pada umumnya model penelitian dan pengembangan merupakan metode yang cocok untuk mengembangkan dan menguji suatu produk. Adapun langkahlangkah dari tahapan pengembangannya adalah sebagai berikut: 
a. Melakukan penelitian pendahuluan, yang meliputi:

1) Identifikasi kebutuhan pembelajaran dan menentukan standar kompetensi mata pelajaran

2) Melakukan analisis pembelajaran

3) Mengidentifikasi karakteristik dan perilaku awal siswa

4) Menulis kompetensi dasar dan indikatornya

5) Menulis tes acuan patokan

6) Menyusun strategi pembelajaran yang diwujudkan dalam bentuk silabus dan satuan pembelajaran

7) Mengembangkan materi pembelajaran

b. Pembuatan desain software, yang meliputi :

1) Pembuatan naskah

2) Pembuatan storyboard

3) Pembuatan flowchart view

c. Pengumpulan bahan, yang meliputi :

1) Pembuatan dan pengumpulan gambar (image) dan animasi

2) Perekaman dan pengumpulan audio

d. Pengembangan bahan ajar pembelajaran, terbagi atas 2 jenis yaitu: (1) Pengembangan konten, (2) Pengembangan media interaktif yang meliputi : pembuatan desain, pengumpulan bahan atau materi media interaktif dan pembuatan media interaktif serta pengembangannya.

e. Review dan revisi media pembelajaran interaktif

f. Uji coba produk awal media pembelajaran interaktif

\section{Prosedur Pengembangan}

Untuk menghasilkan produk media pembelajaran interaktif, peneliti melakukan langkah-langkah sebagai prosedur pengembangan dengan model pengembangan Dick, Carey, \& Carey (2005: 1) yang terbagi atas lima tahapan, yaitu : Tahap pertama melakukaan penelitian pendahuluan, dimana pada tahap ini dilakukan identifikasi kebutuhan pembelajaran dan menentukan standar kompetensi pelajaran, melakukan analisis pembelajaran, mengidentifikasi karakteristik dan perilaku awal siswa, menuliskan kompetensi dasar dan indikatornya, menulis tes acuan patokan, menyusun strategi pembelajaran yang diwujudkan dalam bentuk silabus dan satuan pembelajaran serta mengembangkan materi pembelajaran.

Tahap kedua adalah pembuatan desain media pada tahap ini diawali dengan pembuatan desain software, pembuatan naskah, pembuatan storyboard, pembuatan flowchart view. Tahap ketiga adalah pengumpulan bahan diawali dengan pengumpulan bahan pembuatan dan pengumpulan gambar animasi, perekaman dan audio. Tahap keempat adalah membuat dan memproduksi media pengembangan bahan ajar pembelajaran, yang dilengkapi dengan petunjuk-petunjuk media seperti petunjuk belajar, deskripsi deskripsi singkat, kompetensi dasar, uraian materi, soal-soal latihan dan balikan serta rangkuman. Tahap kelima adalah review dan uji lapangan dalam rangka evaluasi formatif dan revisi produk. Evaluasi formatif terus berlangsung selama proses pengembangan Untuk melakukan review atau uji lapangan diambil dari hasil evaluasi formatif dan revisi produk. Evaluasi formatif terus berlangsung selama proses pengembangan mulai dari tahap analisis, desain, produksi maupun implementasi sampai diperoleh hasil yang sesuai dengan tujuan yang telah ditetapkan.

Dalam penelitian ini, data yang diambil sebagai dasar dalam menetapkan kelayakan dan daya tarik terhadap produk yang dikembangkan sebelum dipakai di lapangan. Data yang digunakan dalam penelitian ini adalah sebagai berikut : (1) untuk aspek pembelajaran dan kebenaran isi diperoleh dari ahli materi pembelajaran dan desain pembelajaran, (2) untuk aspek media diperoleh dari ahli media, (3) untuk aspek kualitas tampilan dan penyajian materi, diperoleh dari uji coba perorangan, kelompok kecil, dan lapangan, (4) untuk aspek daya tarik media interaktif diperoleh dari aktifitas dan respon peserta didik selama dilakukan uji coba media pembelajaran interaktif tersebut, dan (5) untuk aspek keefektifan media pembelajaran interaktif, diperoleh dari proses pengembangan kosakata Bahasa Inggris dengan menggunakan media pembelajaran interaktif dan dibandingkan dengan hasil belajar siswa yang menggunakan buku cetak.

Teknik pengumpulan data yang dipergunakan dalam penelitian ini adalah sebagai berikut: (1) Angket, digunakan untuk 
menjaring data kebutuhan multimedia interaktif yang diberikan kepada guru dan siswa, untuk mengidentifikasi kebutuhan dan tujuan umum pembelajaran, untuk menjaring pendapat teknologi pendidikan, bidang studi, dan siswa, (2) Tes Hasil belajar, digunakan untuk mendapatkan data tentang perolehan hasil belajar siswa pada pembelajaran dan untuk mengetahui efektifitas multimedia interaktif pada pembelajaran yang dikembangkan, (3) Observasi, digunakan untuk mengevaluasi kemampuan guru, kemampuan siswa, kondisi lingkungan saran dan prasarana yang ada serta data tentang kemungkinan siswa untuk mengikuti pembelajaran menggunakan multimedia interaktif dan evaluasi proses uji coba, (4) Dokumentasi, digunakan untuk melengkapi data hasil angket, observasi, dan wawancara juga digunakan untuk mengungkap ketersediaan bahan/dokumentasi yang ada.

\section{HASIL DAN PEMBAHASAN Hasil}

Hasil penelusuran dari angket yang disebar ditemukan bahwa $75 \%$ dari guru menyatakan membutuhkan media pembelajaran interaktif dalam proses pembelajaran agar proses pembelajaran berjalan lebih efektif, dan $100 \%$ siswa menyatakan membutuhkan sarana pembelajaran secara individual. Berdasarkan validasi produk melalui serangkaian uji coba dan revisi yang telah dilakukan, maka media pembelajaran interaktif pada mata pelajaran Bahasa Inggris telah memiliki status valid. Uji coba dilakukan pada 4 tahap yaitu: (1) evaluasi ahli materi, ahli desain pembelajaran dan ahli rekayasa perangkat lunak dan desain grafis, (2) uji coba perorangan, (3) uji coba kelompok kecil, dan (4) uji coba lapangan

Ahli materi menilai media pembelajaran Bahasa Inggris berbasis multimedia interaktif berdasarkan tiga aspek yaitu kualitas materi pembelajaran, kualitas strategi pembelajaran dan kualitas sistem penyampaian pembelajaran yang menunjukkan persentase rata-rata penilaian masing-masing $96,25 \%$ pada aspek kualitas materi pembelajaran, $94,00 \%$ pada aspek kualitas strategi pembelajaran, dan 95,00\% pada aspek sistem penyampaian pembelajaran termasuk kategori Sangat Sesuai secara keseluruhan, yang berarti media pembelajaran Bahasa Inggris berbasis multimedia interaktif dapat memenuhi tuntutan kebutuhan pembelajaran. Penilaian ahli desain pemeblajaran terhadap aspek kualitas desain pembelajaran menunjukkan persentase ratarata 95,00\% termasuk kategori Sangat Sesuai yang berarti penampilan fisik media pembelajaran Bahasa Inggris berbasis multimedia interaktif berfungsi dalam meningkatkan motivasi belajar peserta didik. Penilaian ahli desain pembelajaran terhadap aspek kualitas desain informasi menunjukkan persentase rata-rata $92,50 \%$ termasuk kategori Sangat Sesuai, yang berarti informasi media pembelajaran Bahasa Inggris berbasis multimedia interaktif dapat memberikan kemudahan bagi siswa untuk memperoleh informasi yang diinginkan. Penilaian ahli desain pembelajaran terhadap aspek kualitas desain interaksi menunjukkan persentase ratarata 90,00\% termasuk kategori Sangat Sesuai yang berarti pengaturan isi pembelajaran memperhatikan aspek interaksi antara peserta siswa dengan pembelajaran sehingga dapat tercipta suatu kondisi yang mampu memfasilitasi belajar. Sedangkan persentase rata-rata pada aspek desain presentasi adalah 98,33 \% termasuk kategori Sangat Sesuai yang berarti presentasi dari media pembelajaran interaktif yang dikembangkan memiliki tampilan yang menarik sehingga mampu menimbulkan rasa ketertarikan siswa untuk melakukan pembelajaran. Berdasarkan hasil penilaian pada media pembelajaran Bahasa Inggris berbasis multimedia interaktif pada uji coba perorangan tidak terdapat saran perbaikan.

Hasil penelitian terhadap media pembelajaran Bahasa Inggris Berbasis Multimedia Interaktif pada uji coba kelompok kecil di SD IT Al Iklas Kelas IV terhadap aspek kualitas materi pembelajaran adalah sebesar 91,39\% dan aspek kualitas teknis atau tampilan sebesar 95,87\% dan masing-masing termasuk kategori Sangat Sesuai. Dengan demikian, hasil penilaian yang dilakukan terhadap media Bahasa Inggris Berbasis Multimedia Interaktif uji coba kelompok kecil secara keseluruhan adalah Sangat Sesuai dan setelah dianalisis tidak terdapat masalah yang harus diperbaiki. 
Hasil penilaian terhadap media pembelajaran Bahasa Inggris Berbasis Multimedia Interaktif pada uji coba lapangan menunjukkan bahwa produk yang dikembangkan Sangat Sesuai atau layak digunakan dan tidak ada saran perbaikan yang disampaikan pada uji coba lapangan ini sehingga tidak dilakukan revisi IV.

Uji coba lapangan juga dilakukan di SD IT Al Iklas Medan. Uji coba lapangan dilakukan terhadap siswa SD IT Al Iklas
Medan kelas IV yang terdiri dari 60 siswa yakni kelas A sebanyak 30 siswa dan kelas B sebanyak 30 siswa. Uji coba lapangan menghasilkan data-data yang nantinya akan mengukur kelayakan dari produk yang dikembangkan, serta untuk mengetahui bagaimana manfaat produk tersebut bagi pemakainya. Hasil evaluasi terhadap media pembelajaran pada aspek kualitas materi pembelajaran dapat dilihat pada Tabel 38.

Tabel 1. Skor Penilaian Media Pembelajaran Bahasa Inggris Berbasis Multimedia Interaktif di SD Al Iklas Kelas IV pada Aspek Kualitas Materi Pembelajaran

\begin{tabular}{|c|c|c|c|c|c|c|c|}
\hline \multirow{2}{*}{ No } & \multirow{2}{*}{ Indikator Penilaian } & \multicolumn{4}{|c|}{ Skor } & \multirow{2}{*}{$\begin{array}{l}\text { Rata- } \\
\text { rata }\end{array}$} & \multirow{2}{*}{ Kriteria } \\
\hline & & \begin{tabular}{l|l}
1 & 2
\end{tabular} & 3 & 4 & 5 & & \\
\hline 1 & Kesesuaian materi & & & 10 & 20 & $93,33 \%$ & Sangat Sesuai \\
\hline 2 & Kejelasan petunjuk belajar & & & 9 & 21 & $94,00 \%$ & Sangat Sesuai \\
\hline 3 & $\begin{array}{l}\text { Kemudahan memahami kalimat } \\
\text { pada teks }\end{array}$ & & & 19 & 11 & $87,33 \%$ & Sangat Sesuai \\
\hline 4 & $\begin{array}{l}\text { Kemudahan memahami } \\
\text { pembelajaran }\end{array}$ & & & 14 & 16 & $90,67 \%$ & Sangat Sesuai \\
\hline 5 & Ketepatan urutan penyajian & & & 17 & 13 & $88,67 \%$ & Sangat Sesuai \\
\hline 6 & Kecukupan latihan & & & 15 & 15 & $90,00 \%$ & Sangat Sesuai \\
\hline 7 & Kejelasan umpan balik & & & 9 & 21 & $94,00 \%$ & Sangat Sesuai \\
\hline 8 & Bantuan belajar dengan program & & & 6 & 24 & $96,00 \%$ & Sangat Sesuai \\
\hline \multicolumn{6}{|c|}{ Rata-rata } & $\begin{array}{c}97,84 \\
\% \\
\end{array}$ & $\begin{array}{l}\text { Sangat } \\
\text { Sesuai }\end{array}$ \\
\hline
\end{tabular}

Tabel 2. Skor Penilaian Media Pembelajaran Interaktfi Berbasis Komputer Pada Mata Pelajaran Bahasa Inggris Uji Coba Lapangan di SD Al Iklas Kelas IV Pada Aspek Kualitas Teknis atau Tampilan

\begin{tabular}{|l|l|l|l|l|l|l|l|l|}
\hline \multirow{2}{*}{ No } & \multirow{2}{*}{ Indikator Penilaian } & \multicolumn{5}{|c|}{ Skor } & \multirow{2}{*}{ Rata-rata } & \multirow{2}{*}{ Kriteria } \\
\cline { 2 - 7 } & 1 & 2 & 3 & 4 & 5 & & \\
\hline 1 & Keindahan tampilan layar & & & & 13 & 17 & $91,33 \%$ & Sangat Sesuai \\
\hline 2 & Keterbacaan teks & & & & 15 & 15 & $90,00 \%$ & Sangat Sesuai \\
\hline 3 & $\begin{array}{l}\text { Kualitas gambar dan } \\
\text { animasi }\end{array}$ & & & 18 & 12 & $88,00 \%$ & Sangat Sesuai \\
\hline 4 & Komposisi warna & & & & 18 & 12 & $88,00 \%$ & Sangat Sesuai \\
\hline 5 & Navigasi & & & & 13 & 17 & $91,33 \%$ & Sangat Sesuai \\
\hline 6 & Daya dukung musik & & & & 13 & 17 & $91,33 \%$ & Sangat Sesuai \\
\hline 7 & Interaksi Rata-rata & & & & 12 & 18 & $92,00 \%$ & Sangat Sesuai \\
\hline \multicolumn{2}{|r|}{} & & & & & $\mathbf{9 8 , 0 8 \%}$ & Sangat Sesuai \\
\hline
\end{tabular}


Hasil penilaian uji coba lapangan terhadap aspek kualitas materi pembelajaran pada media pembelajaran Bahasa Inggris berbasis multimedia interaktif telah dirangkum pada Tabel 3.

Hasil tanggapan siswa menyatakan bahwa untuk aspek kualitas materi pembelajaran pada uji coba lapangan di SDIT Al Iklas Kelas IV menunjukkan 60 orang $(100 \%)$ menyatakan "Sangat Sesuai". Hasil tanggapan siswa tersebut dapat dilihat pada Tabel 3.

Tabel 3. Tingkat kecenderungan Penilaian Terhadap Aspek Kualitas materi

\begin{tabular}{|c|l|c|c|c|}
\hline No. & \multicolumn{1}{|c|}{ Kategorisasi } & Persentase & Frekuensi & Persentase \\
\hline 1 & Sangat sesuai & $81 \% \leq \times \leq 100 \%$ & 60 & $100,00 \%$ \\
\hline 2 & Sesuai & $61 \% \leq \times<80 \%$ & 0 & $0,00 \%$ \\
\hline 3 & Cukup sesuai & $41 \% \leq \times<60 \%$ & 0 & $0,00 \%$ \\
\hline 4 & Kurang sesuai & $21 \% \leq \times<40 \%$ & 0 & $0,00 \%$ \\
\hline 5 & Sangat kurang sesuai & $0 \% \leq \times<20 \%$ & 0 & $0,00 \%$ \\
\hline \multicolumn{2}{|c|}{ Jumlah } & 60 & $100,00 \%$ \\
\hline
\end{tabular}

Berdasarkan penilaian terhadap media pembelajaran Bahasa Inggris Berbasis Multimedia Interaktif pada uji coba lapangan dengan 60 siswa SD IT Al Iklas Medan untuk aspek kualitas materi pembelajaran dan aspek kualitas teknis/tampilan menunjukkan bahwa produk yang dikembangkan Sangat Sesuai atau layak digunakan.

Hipotesis 2

Maka selanjutnya untuk pengujian hipotesis 2 dapat menggunakan Uji t Pre-Test dan Uji t Post-Test.

1. Uji t Pre-Test

Setelah uji kelayakan data selesai dilaksanakan, maka selanjutnya dilakukan uji t pre-test penelitian. Hal ini dilakukan untuk mengetahui apakah terdapat perbedaan kemampuan awal kelas kontrol dan kelas eksperimen dengan menggunakan uji t pretest.

Berdasarkan hasil perhitungan yang terdapat pada lampiran 4, diperoleh output thitung sebesar -2,31 dan $t_{\text {tabel }}$ sebesar 1,67 pada taraf kepercayaan 95 persen. Maka diperoleh bahwa $\mathrm{t}_{\text {hitung }}<\mathrm{t}_{\text {tabel }}$ atau $-2,31<1,67$ atau dengan kata lain $\mathrm{Ha}$ ditolak. Hal ini menunjukkan bahwa kemampuan awal siswa kelas kontrol dan kelas eksperimen adalah cenderung sama dan tidak berbeda secara signifikan.

Uji t Post-Test
Setelah uji t pre-test selesai dilaksanakan, maka selanjutnya dilakukan pengujian hipotesis penelitian dengan menggunakan uji $\mathrm{t}$ post-test. Hal ini dilakukan untuk mengetahui apakah ada perbedaan hasil belajar siswa setelah dilakukan perlakuan yang berbeda. Hipotesis penelitian ini adalah sebagai berikut:

Ha : Media pembelajaran yang dikembangkan mampu meningkatkan hasil belajar Bahasa Inggris

Ho : Media pembelajaran yang dikembangkan tidak mampu meningkatkan hasil belajar Bahasa Inggris

Berdasarkan penelitian yang telah dilakukan terhadap hasil belajar Bahasa Inggris pada siswa yang dibelajarkan dengan media pembelajaran interaktif, ditemukan bahwa skor hasil belajar siswa dari 30 responden tersebar pada rentang 50-100. Dari hasil perhitungan menunjukkan bahwa skor terendah 50 dan skor tertinggi 100, mean 72,50, median 70 dan standar deviasi 9,45. Berdasarkan hasil perhitungan, maka diperoleh data bahwa $t_{\text {hitung }}>t_{\text {tabel }}$ atau 4,51 > 1,67 atau dengan kata lain $\mathrm{H} 0$ ditolak dan $\mathrm{Ha}$ diterima, maka dapatlah disimpulkan bahwa hasil belajar Bahasa Inggris siswa yang menggunakan media pembelajaran multimedia interaktif lebih tinggi dari siswa yang diajar dengan menggunakan buku teks 
dengan efektifitas penggunaan media interaktif sebesar 73,67\%.

\section{Pembahasan}

Produk pengembangan media pembelajaran media pembelajaran interaktif pada mata pelajaran Bahasa Inggris merupakan materi pembelajaran yang telah dikembangkan dengan memperhatikan aspek pembelajaran dan media sebagai prinsip desain pesan pembelajaran. Penelitian pengembangan produk yang dilakukan ini diarahkan untuk menghasilkan suatu produk berupa media pembelajaran Bahasa Inggris Berbasis Multimedia Interaktif untuk siswa SD IT Al Iklas Medan yang digunakan untuk meningkatkan proses pembelajaran maupun kompetensi siswa. Oleh sebab itu proses penelitian ini dilakukan dan diawali dengan (1) studi pendahuluan, (2) kemudian mendesain media pembelajaran, (3) melakukan validasi produk, dan (4) melakukan revisi dan penyempurnaan berdasarkan analisis data validasi dari ahli materi, ahli desain pembelajaran dan ahli rekayasa perangkat lunak yang dilanjutkan dengan uji coba perorangan, uji coba kelompok kecil, dan uji coba lapangan sehingga dihasilkan media pembelajaran yang layak digunakan sesuai dengan karakteristik bidang studi dan siswa sebagai pengguna.

Aspek yang direvisi dan disempurnakan berdasarkan analisis data dan uji coba serta masukan dari ahli materi, ahli desain pembelajaran, ahli rekayasa perangkat lunak dan siswa selaku pengguna media pembelajaran interaktif ini, bertujuan untuk menggali beberapa aspek yang lazim dalam proses pengembangan suatu produk. Variabelvariabel media pembelajaran memiliki nilai rata-rata Sangat Sesuai. Adapun variabel media pembelajaran yang dinilai meliputi kelayakan isi, penyajian, kebahasaan, dan kegrafikan.

Manfaat dalam penggunaan media pembelajaran Bahasa Inggris Berbasis Multimedia Interaktif adalah sebagai berikut: (1) materi mudah dipahami karena konsep yang disajikan direncanakan untuk mempermudah siswa dan sistematis, (2) media pembelajaran Bahasa Inggris berbasis multimedia interaktif memberi kesempatan siswa untuk belajar sesuai degan kecepatan masing-masing individu, (3) belajar lebih cepat dan menarik sehingga tidak menimbulkan kebosanan karena dilengkapi dengan gambar-gambar dan animasi serta soal latihan yang bervariasi, (4) adanya kesempatan dalam menjawab soal pada waktu tes jika jawaban dianggap salah dengan tujuan agar siswa dapat memahami materi yang telah dipelajari, (5) media pembelajaran interaktif ini juga dapat digunakan sebagai alternatif media pembelajaran secara individual.

Dari hasil pengolahan data penelitian yang dilakukan, terdapat perbedaan hasil belajar kosakata Bahasa Inggris antara siswa yang dibelajarkan dengan menggunakan media pembelajaran interaktif dan siswa yang dibelajarkan dengan tanpa media pembelajaran interaktif yaitu rata-rata hasil belajar kosakata Bahasa Inggris siswa yang dibelajarkan dengan menggunakan media pembelajaran interaktif lebih tinggi dibandingkan dengan siswa yang dibelajarkan tanpa menggunakan media pembelajaran interaktif. Maka, media yang telah dihasilkan adalah layak dan efektif untuk digunakan dalam pembelajaran. Hal ini sesuai dengan pendapat pakar dan hasil penelitian yang relevan sebagai berikut:

1) Keunggulan penggunaan multimedia interaktif dalam pembelajaran adalah seperti yang diungkapkan oleh Wood (2001: 15), penggunaan multimedia pembelajaran berpotensi meningkatkan pembelajaran kosakata.

2) Teori pengajaran dari ahli psikologi Jerome Bruner (1995) yang menyatakan bahwa pengajaran seharusnya dimulai dari pengalaman langsung menuju representasi ikonik dan baru kemudian menuju representasi simbolik.

3) Hasil penelitian yang relevan. Penelitian yang dilakukan oleh Katz, D (2002: 72-76) membuktikan bahwa penggunaan multimedia dalam pembelajaran bahasa asing sangat membantu siswa, membuat mereka merasa senang dan menjadikan mereka lebih aktif dan mengurangi waktu guru untuk banyak menjelaskan.

4) Kerangka Berpikir

Multimedia pembelajaran adalah paket multimedia interaktif di mana di dalamnya terdapat langkah-langkah instruksional yang didisain untuk melibatkan pengguna 
secara aktif di dalam proses pembelajaran. Keunggulan paling menonjol yang dimiliki multimedia adalah interaktivitas. Interaktivitas secara fisik dalam multimedia pembelajaran bervariasi dari yang paling sederhana hingga yang kompleks. Multimedia interaktif memungkinkan adanya interaksi langsung antara siswa dan masalahnya. Siswa tidak hanya diajak bicara atau membaca tentang sesuatu masalah tapi juga diajak untuk berkontak secara langsung dengan masalahnya untuk menghasilkan keseragaman pengamatan. Hal ini karena adanya persepsi yang pernah berbeda antara yang pernah melihat, mendengar dan yang mengalami kini dipersatukan dengan melihat, mendengar dan mengalami bersama. Dengan menggunakan multimedia interaktif siswa dapat berinteraksi langsung dengan media sehingga proses pemahaman akan terjadi lebih cepat. Multimedia yang dikemas mengandung unsur pendidikan dan hiburan (edutainment) merupakan kemasan yang memberikan pengalaman belajar yang mengesankan bagi siswa. Media pembelajaran ini sangat praktis, karena media ini dapat dibawa oleh siswa dan dapat dipelajari dirumah karena media pembelajaran interaktif tersebut dalam bentuk CD (compact disk) yang ringan. Media pembelajaran ini juga dapat menguji kemampuan dan pemahaman siswa secara langsung melalui tes atau soal-soal latihan yang memiliki durasi waktu dan kunci jawaban yang benar, sehingga siswa dapat mengetahui kesalahan yang telah dilakukan dalam mengerjakan soal latihan tersebut. Media pembelajaran interaktif juga dilengkapi dengan rangkuman yang dapat membantu siswa memperoleh ringkasan materi pelajaran yang dipaparkan. Tanpa media pembelajaran Bahasa Inggris berbasis multimedia interaktif siswa mendapatkan sumber informasi hanya dari guru yang bersangkutan dengan materi-materi yang ada pada buku, membuat guru menggunakan kontrol pembelajaran dengan aktif, sementara siswa relatif pasif menerima dan mengikuti apa yang disampaikan guru.

\section{PENUTUP \\ Simpulan}

Berdasarkan kualitas dan hasil implementasi multimedia interaktif kosakata Bahasa Inggris yang telah teruji pada siswa kelas IV SD IT Al Iklas Medan, maka dapat disimpulkan sebagai berikut: (1) Hasil validasi dari ahli materi, ahli desain pembelajaran dan ahli desain grafis menyatakan bahwa multimedia interaktif yang dihasilkan layak untuk digunakan dalam pembelajaran dan (2) Hasil belajar siswa yang diajarkan dengan menggunakan multimedia interaktif lebih efektif

\section{Saran}

Berdasarkan hasil temuan yang telah diuraikan pada kesimpulan dan hasil penelitian, berikut ini diajukan beberapa saran, yaitu: (1) Kepala sekolah sebagai creator dan motivator harus mampu melihat dan mau mendengar keinginan guru, mau belajar untuk menciptakan perubahanperubahan penerapan teknologi pembelajaran sehingga dapat mengupayakan pengadaan dana untuk pengadaan media pembelajaran, dan (2) Media pembelajaran kosakata Bahasa Inggris berbasis multimedia interaktif memerlukan adanya komputer sehingga hendaknya komputer yang ada di laboratorium komputer sekolah ditambah sesuai dengan jumlah siswa.

\section{DAFTAR PUSTAKA}

Ahmad. (2012)

Perencanaan

Pembelajaran.Yogyakarta: Pustaka Insan Madani

Apriliantoro. (2013). Pengembangan Media Pembelajaran Jaringan Komputer Berbasis Macromedia Flash. Skripsi. Universitas Negeri Semarang.

Arsyad. (2002). Media Pembelajaran, edisi 1. Jakarta: Raja Grafindo Persada . ( 2011). Media Pembelajaran. Jakarta: Raja Grafindo Persada (2013). Media Pembelajaran. Jakarta: Rajawali Press.

Astutik. (2012). Pengembangan Media Pembelajaran Membaca Aksara Jawa Berbasis Macromedia Flash. Skripsi. Universitas Negeri Malang. 
Basuki. (2012). Pengembangan Media Pembelajaran Interaktif Berbasis Komputer Pada Mata Kuliah Menggambar Teknik

Borg, W R \& Gall, M D. (2003). Educational Research: an Introduction (7. ed).New York: Logman Inc. . (2005). Educational research: an introduction, Fourth Edition. New York: Longman. Inc.

Brown, J. W.,Lewis, R. B.,\& Harcleroad, F. F. (1977). AV instruction Technology, media, and methods. New York: McGraw-Hill.

Budiningsih, C. A. (2005). Belajar dan Pembelajaran. Jakarta: Rineka Cipta.

Cahyadi, V. (2004). The effect of interactive engagement teaching on student understanding of introductory physics at the faculty of engineering, University of Surabaya, Indonesia. Jurnal Vol. 23, No. 4, November 2004. Higher Education Research \& Development 2004.

DOI: $10.1080 / 0729436042000276468$

Cameron. (2001). Teaching Languages to Young Learners. UK: Cambridge University Press.

Darmawan. (2011). Teknologi Pembelajaran. Bandung: Rosdakarya Offset.

Dick, W., Carey, L. \& Carey, J. O. (2005). The systematic design of instruction.Boston: Harper Collin College Publisher

Dimyati dan Mudjiono. (2013). Belajar dan Pembelajaran. Jakarta: Rineka Cipta.

Droga, L., \& Humphrey, S. (2003). Grammar and Meaning: an Introduction for Primary Teachers. Berry, Australia: Target Texts.

Hamalik, O. (2006). Media Pendidikan, cetakan ke-7. Bandung: Penerbit Citra Bakti.

Hamalik, O. (2006). Proses Belajar Mengajar. Jakarta: PT Bumi Aksara.

Heinich, R., \& Heinich, R. (2011). Instructional media and technologies forLearning. Englewood Cliffs, N.J: Merrill.

Heinich, R., et al (1993). Instructional media and technologies for learning Englewood Cliffs, N.J: Merrill
Hurlock. (2005), Psikologi Perkembangan suatu Pendekatan Rentang Kehidupan. Jakarta : Erlangga.

Ikasari, D.W.S. \& Zaerofi, A. (2005). Eglish friendly: fun engglish for theelementary school students for grade 4. Solo: Tiga Serangkai.

Just another WordPress.com site. June 5, 2011. Materi mata kuliah media. wordpress.com/2011/06/05/materimata-kuliah-media/ Kridalaksana, Harimurti. (2009).

Kamus Linguistik. Edisi Keempat. Jakarta: Gramedia Pustaka Utama.

Lehrer, K. (2000). Theory of Knowledge. 2nd Edition. Boulder: Westview Press.

Miarso. (2011). Menyemai Benih Pendidikan. Jakarta: Teknologi Prenada Media

Nunan, D. (1992). Research Method in Education. Cambridge University Press.

(1991). Language Teaching Methodology. New York: Prentice Hall.

Rohani, Ahmad. (1997). Media Instruksional Edukatif. Jakarta : Penerbit, Rineka Cipta.

Rusman, (2005). Model-model Multimedia Interaktif Berbasis Komputer. Jakarta: UPI.

Sadiman, dkk. (2010 ). Media Pembelajaran. Jakarta: PT. Raja Grafindo Persada. . (2008). Media Pendidikan. Jakarta: Raja Garafindo Persada Cipta.

Sardiman, A. M. (2004). Interaksi \& motivasi belajar mengajar. Jakarta: Raja Grafindo Persada Rajawali Pers.

Seels, B.B. \& Richey, R.C. (1994). Instructional technology: the definition anddomains of the field. (Terjemahan Yusuf Hadi Miarso, Dewi S Prawiradilaga \& Raphael Rahardjo. IPTPI, Unit Percetakan UNJ).

Sharon, et al.(2011). Instructional Technology \& Media For learning. Jakarta :Prenada Media Group.

Slavin, R.E. (2000). Educational Psychology: Theory and Practice. 6th. Ed.Boston: Allyn and Bacon.

Suardiman. (1995). Perkembangan Peserta Didik. Yogyakarta: UNY. (2006). Perkembangan Peserta Didik. Yogyakarta: UNY. 
Sudjana, N. (2010). Penilaian Hasil Proses Belajar Mengajar. Bandung: Ramaja Rosdakarya.

Suryabrata, Sumadi. (1984). Metodologi Penelitian. Jakarta : CV. Rajawali.

Suyanto. (2005). Multimedia Alat Untuk Meningkatkan Keunggulan Bersaing. Yogyakarta : Penerbit Andi

Trianto. (2007). Model Pembelajaran Inovatif Berorientasi Konstruktivistik.Surabaya: Pustaka.

Cornely, V. (2014). The Influence Of Using Crossword Puzzle On The Students Writing (An Experimental Grade of SDN Picung Remuk 2 Tasikmalaya). Jurnal Universitas Siliwangi
Winkel, W. S. (2004). Psikologi Pendidikan dan Evaluasi belajar. Jakarta: Gramedia.

Wood, J. (2001). Can software support children's vocabulary development? [versi elektronik]. Journal of Language Learning \& Technology, 5, 166-265.

Yunisah, Aris. (2007). Pengaruh Media Audio Visual Terhadap Penguasaan Kosakata Bahasa Indonesia Siswa Kelas VII SMP 1 Depok, Sleman, Yogyakarta. Skripsi. FBS-UNY.

Yusuf. (2005). Psikologi perkembangan anak \& remaja. Bandung, Indonesia: Remaja Rosdakarya. 